\title{
TIMING OF HIBERNATION AND MOLT IN FEMALE COLUMBIAN GROUND SQUIRRELS
}

\author{
Peter Neuhaus* \\ Natural History Museum Bern, University of Bern, Bernastrasse 15, 3005 Bern, Switzerland \\ Present address: Department of Zoology, University of Cambridge, Downing Street, \\ Cambridge CB2 3EJ, United Kingdom
}

Timing of activity, seasonal changes in food availability, environmental fluctuations, and costs of reproduction are important determinants of an animal's life history. In mountain ground squirrels (Spermophilus), the shortness of the active season influences how they time their activities. I studied timing of the active season, reproduction, and weight loss during hibernation in Columbian ground squirrels ( $S$. columbianus) in Alberta, Canada, from the summer of 1994 to the spring of 1998. Entry into hibernation and emergence from hibernation the following year were earlier for females that did not wean a litter compared with those that did. The active season was shorter and hibernation longer for unsuccessful females than for successful females. Molt of females was earlier when they did not wean a litter than when they did. Date of mating had no influence on success in weaning a litter, but juveniles surviving to yearling age came from litters born earlier than juveniles that did not survive to yearling age. In successfully reproducing females, early entry into hibernation was associated with early mating. Daily and total weight loss during hibernation was higher in females that weaned young than in females that did not wean young.

Key words: body mass, ground squirrel, hibernation, molt, reproduction, Spermophilus columbianus

Herbivores in temperate zones are faced with a short growing season of plants. Often only 1 season of the year is ideal for raising young, and thus timing of breeding is important for maximizing reproductive success. Because reproduction is energetically costly, parents should try to optimize timing of reproduction to minimize net energy expenditure and maximize investment in offspring. In many birds (Gauthier 1989; Morton and Derrickson 1990; Olsson 1996; Schoech 1996; Verhulst and Tinbergen 1991), black-tailed prairie dogs (Cynomys ludovicianus-Hoogland 1995), Unita ground squirrels ( $S$. armatus-Rieger 1996), and Columbian ground squirrels ( $S$. columbianus-Murie and Harris 1982), ear-

\footnotetext{
*Correspondent: peter_neuhaus@hotmail.com
}

ly mating results in higher reproductive success. Many factors affect timing of mating, such as food availability (Ben-David 1997; Benkman 1990; Churchill 1994; Komdeur 1996; Schoech 1996; Young 1996), parasite abundance (Oppliger et al. 1994), weather conditions, (Grindall et al. 1992; Murie and Harris 1982), parental body condition (Mitchell and Lincoln 1973; Newton and Marquiss 1984), quality of habitat, and parental experience (Gauthier 1989; Morton and Derrickson 1990).

When the limiting factor is energy, which depends largely on food availability, the most efficient timing for reproduction might not be the same for parents and young. Females need the most energy during gestation and while their young are still fed by 
one or both parents. Young need enough energy, just after independence from their parents, to grow and accumulate body reserves to survive when food is least abundant. Females therefore have to balance maximum energy demands of lactation with the need for offspring to grow and fatten after weaning.

I studied the interplay between reproductive events and timing of the short active season in Columbian ground squirrels by evaluating how reproductive costs affect timing of hibernation, timing of the molt, and weight loss during hibernation. Adult female Columbian ground squirrels emerge from hibernation before plants begin their annual growth. An early start of the active season might be caused by the need for young to have enough time to grow and fatten before entering hibernation (Barash 1989; Michener 1985).

Young Columbian ground squirrels first emerged from their natal burrows between mid-June and early July, entering hibernation (immerging) around mid-August. Consequently, young have little more than a month of active time to grow and accumulate enough fat for their 1st long and energy-consuming hibernation. Adult female Columbian ground squirrels also have a short active season of about 4 months in which they mate, lactate, wean young, and molt and fatten in preparation for hibernation. The decline of energy and water content in vegetation as summer progresses may be the primary reason for early immergence and the subsequent 8-month-long hibernation of these animals (Ritchie 1990). During lactation, female Richardson's ground squirrels (S. richardsonii) invest all their available energy into their offspring (Michener 1989), leaving them with only the time after weaning to accumulate enough fat reserves for hibernation. Mothers and their offspring must not only fatten for the upcoming 8 months of inactivity but also molt before hibernating. Molt itself is energy consuming, as shown in birds (Klaassen 1995; Siikamäki et al. 1994), Eu- ropean badgers (Meles meles-Stewart and MacDonald 1997), and Candabrian chamois (Rupicapra pyrenaica parva-PerézBarbería and Nores 1996). Columbian ground squirrels hibernate individually (Young 1990), unlike the alpine marmot (Marmota marmota), which hibernates in groups, allowing adults to help young conserve their fat reserves by group huddling (Arnold 1990). Therefore, young ground squirrels need to achieve some minimum body size and to accumulate enough fat for hibernation. Hence, the short growing season of plants and the long period of hibernation require precise timing for females and their offspring.

Reproduction could influence negatively weight gain during the active season and survival of adult females. I evaluated possible proximate mechanisms that could account for costs of reproduction. I studied timing of immergence and emergence and molt to test the hypothesis that energetic costs of reproduction would delay these events. I also studied total, daily, and proportional weight loss during hibernation to determine whether energetic costs of reproduction have a negative influence on performance of females during hibernation. I evaluated the influence of the date of mating on reproductive success, recruitment of yearlings, and time of immergence of the females.

\section{MAterials AND Methods}

Columbian ground squirrels were studied in the Sheep River Wildlife Sanctuary, Alberta, Canada $\left(110^{\circ} \mathrm{W}, 50^{\circ} \mathrm{N}\right)$ in $1994-1998$ in a subalpine meadow of about 2.5 ha at an elevation of $1,550 \mathrm{~m}$ inhabited by 150-250 squirrels. Ground squirrels were active only for about 4 months each year, hibernating during the remaining 8 months (Dobson et al. 1992; Murie and Harris 1982). Females usually bred within the 1st week after emergence, giving birth 24 days later (Murie and Boag 1984; Murie and Harris 1982). Juveniles emerged, on average, 27 days after birth from the natal burrow and were weaned soon thereafter.

All squirrels were marked for permanent iden- 
tification with numbered fingerling fish tags in both ears. Each individual also received a unique mark with black hair dye (Clairol, 124 natural blue black, type 3 permanent) on its back for identification from a distance. Animals were trapped weekly using 15 - by $15-$ by $48-\mathrm{cm}$ and 13 - by 13 - by $40-\mathrm{cm}$ National and Tomahawk live traps baited with peanut butter and weighed $( \pm 5 \mathrm{~g})$ with a Pesola spring scale. Besides weekly trapping, I caught and weighed animals at emergence from hibernation, mating, and within a few days of immergence; daily observations during those events helped determine the exact date of the event for each individual. Observations were made from 2- to 3-m-high wooden stands with binoculars. To get exact mating dates, females were examined for their sexual condition (degree of swelling of the vulva-Murie and Harris 1982). When no direct observations were available, I backdated mating dates by subtracting 51 days from juvenile emergence (Murie and Harris 1982). I classified females that weaned $\geq 1$ juvenile as successfully reproducing females; females that did not wean juveniles were unsuccessful. If juveniles were not observed or trapped the following year, I assumed that they did not survive to yearling age because neither sex dispersed as juveniles (Boag and Murie 1981).

Ages of most animals were known because they had been previously studied and trapped regularly (Stevens 1998). Age was estimated for squirrels of unknown age on the basis of patterns of sex and weight that indicated whether they were $\leq 3$ years old (King et al. 1991). Dye marks faded during the annual molt of the adults in July and August. Whenever I saw an unmarked animal, I caught it and repainted the marks. In 1997, I noted dates of dyeing squirrels and classified molt as finished when no further dyeing was required.

Statistical analyses.-Squirrels caught for the 1st time after 15 May or for the last time before 15 July were not used in analyses of weights. I must have missed their emergence from or immergence into hibernation because it was unlikely to have occurred at those times (Dobson et al. 1992; Murie and Harris 1982; Young 1990). To calculate daily and total weight loss during hibernation, only animals caught $<1$ day of the observed emergence and immergence date were used.

To examine the influence of timing of mating on timing of immergence in successfully reproducing females, I used the median date of immergence each year to divide females into 2 groups of equal size. To ensure that I did not use data from females that died before going into hibernation, I used only immergence dates of animals that did emerge the following spring.

Growing immature females may exhibit different patterns of reproduction and associated characteristics than adult animals (Dobson and Michener 1995). Because 2-year-old Columbian ground squirrels are still growing in body mass and body size (Boag and Murie 1981), I included only individuals that were $\geq 3$ years old in analyses. All data comparing dates, such as timing of immergence, emergence, molt, or mating, were analyzed with Mann-Whitney $U$-tests. Where data were combined over years, effects of year were eliminated by using individual deviations from yearly averages instead of exact dates. For the comparisons of daily weight loss, total weight loss, and percentage weight loss during hibernation, I used 1-way analysis of variance (Sokal and Rohlf 1995). Daily weight losses and total weight loss were not normally distributed and therefore were log transformed prior to analyses to meet the assumption of normality and homoscedasticity (Norusis 1994). Percentage weight loss was arcsin-square root transformed. Ninety-two individuals were captured in the study. Some were used in this data set more than once in consecutive years; most of those females reproduced in 1 year but not in another year.

\section{RESULTS}

Female Columbian ground squirrels that successfully weaned a litter entered hibernation later than females that did not wean a litter $(Z=-5.29, P<0.001, n=184$; Table 1). Twenty-one of 82 successful females immerged in the 1 st half of all immerging females. Successful females that mated early immerged earlier than late-mating females $(Z=-2.4, P<0.02, n=82$; Table 2). However, mating date was similar for unsuccessful females that emerged late and early $(Z=-0.4, P>0.7, n=99$; Table 2). Whether a female bred successfully also influenced emergence date the following spring $(Z=-2.32, P=0.02, n$ = 184; Table 1). 
TABLE 1.-Mean date of immergence and emergence the following spring and length of the active season and hibernation dependent on reproductive success in Columbian ground squirrels (sample sizes in parentheses).

\begin{tabular}{|c|c|c|c|c|c|c|c|c|}
\hline & \multicolumn{2}{|c|}{ Immergence } & \multicolumn{2}{|c|}{ Emergence } & \multicolumn{2}{|c|}{$\begin{array}{l}\text { Length of } \\
\text { active season }\end{array}$} & \multicolumn{2}{|c|}{$\begin{array}{l}\text { Length of } \\
\text { hibernation }\end{array}$} \\
\hline & Date & $S D$ & Date & $S D$ & Days & $S D$ & Days & $S D$ \\
\hline Females weaning young & 8 August & $9(82)$ & 28 April & $6(82)$ & 103 & $9(87)$ & 263 & $10(82)$ \\
\hline Females not weaning young & 31 July & $8(102)$ & 27 April & $6(102)$ & 95 & $10(104)$ & 270 & $10(102)$ \\
\hline
\end{tabular}

In 1977, the mean date that females that did not wean young finished their molt was 16 July (95\% Confidence interval $=12$ July-20 July, $n=27$ ) but the mean date that females that weaned young finished their molt was 30 July $(95 \% C I=29$ July31 July, $n=32 ; Z=-6, P<0.001)$. The active season was longer for females that weaned young compared with females that did not $(Z=-4.7, P<0.001, n=191$; Table 1), and the following hibernation was significantly shorter for females that weaned a litter compared with females that did not $(Z=-3.34, P<0.001, n=184$; Table 1). Successful and unsuccessful females differed in total weight loss during hibernation $(F=3.80$, d.f. $=1,116, P=$ 0.05; Table 3). During hibernation, females that weaned a litter lost $0.66 \mathrm{~g} / \mathrm{day}$, but females that did not wean a litter lost on average $0.60 \mathrm{~g} /$ day $(F=6.19$, d.f. $=1,116$, $P<0.02$; Table 3 ). Weight loss as a proportion of body mass at immergence was significantly greater in females that successfully weaned young compared with

TABLe 2.-Date of mating in successful and unsuccessful reproducing female Columbian ground squirrels in relation to immergence; females immerging before (early) or after (late) 31 July.

\begin{tabular}{lllll}
\hline & $\begin{array}{c}\text { Immer- } \\
\text { gence }\end{array}$ & Date & $S D$ & $n$ \\
\hline Successful females & Early & 27 April & 5.5 & 21 \\
& Late & 1 May & 6.5 & 61 \\
Unsuccessful females & Early & 2 May & 6.5 & 70 \\
& Late & 2 May & 6.5 & 33 \\
\hline
\end{tabular}

those that did not $(F=10.05$, d.f. $=1,116$, $P=0.002$; Table 3).

Mating date of the mother had little influence on the survival of juveniles to emergence from the natal den; 109 successful females mated, on average, on 1 May $(95 \%$ $C I=29$ April-2 May), and 137 unsuccessful females mated on 2 May $(95 \% C I=1$ May-3 May; $Z=-1.78, P>0.07)$. However, females that successfully weaned $\geq 1$ offspring that survived their 1 st hibernation mated on average on 29 April $(95 \%$ CI = 28 April-1 May), significantly earlier than females weaning young that did not survive (4 May, 95\% CI = 1 May-7 May; $Z=$ $-2.33, P=0.02, n=109)$.

\section{DISCUSSION}

Females that weaned litters immerged later than females that were unsuccessful in weaning offspring, resulting in a longer active season and a shorter hibernation for successful females. Michener (1978) reported a similar pattern in yearling female Richardson's ground squirrels; those that successfully reproduced entered hibernation later than those that did not give birth. The longer active season of those females likely compensates for their higher energy expenditure during reproduction.

It might, however, be difficult to compensate by staying active longer because quality of forage in August is low (Bennett 1997), and the animals must eat more to acquire the same amount of energy as they would have in previous months. Ritchie (1990) suggested that Columbian ground squirrels hibernate early and for a long pe- 
TABLE 3.- Total weight loss as a proportion of immergence weight and daily weight loss during hibernation depending on reproductive success in Columbian ground squirrels (sample sizes in parentheses).

\begin{tabular}{|c|c|c|c|c|c|c|}
\hline & \multicolumn{2}{|c|}{$\begin{array}{l}\text { Total weight loss } \\
\text { during hibernation }\end{array}$} & \multicolumn{2}{|c|}{$\begin{array}{l}\text { Loss as proportion } \\
\text { of immergence weight }\end{array}$} & \multicolumn{2}{|c|}{$\begin{array}{l}\text { Daily weight loss } \\
\text { during hibernation }\end{array}$} \\
\hline & $\mathrm{g}$ & $S D$ & $\%$ & $S D$ & $\mathrm{~g}$ & $S D$ \\
\hline Females weaning young & 174 & $32(46)$ & 30 & $3.9(46)$ & 0.66 & $0.11(46)$ \\
\hline Females not weaning young & 162 & $33(72)$ & 27.5 & $4.6(72)$ & 0.60 & $0.12(72)$ \\
\hline
\end{tabular}

riod primarily because they are unable to meet above-ground energy or water requirements during the time they spend in hibernation. Early immergence of adult males (Young 1990) and unsuccessful females into hibernation also might decrease their vulnerability to predation, increasing risk of predation for the remaining active individuals. Decline of food quality and increased predation pressure likely make it important for animals to immerge as soon as their body condition allows. This creates a tradeoff between declining forage benefit, predation pressure, and ability to accumulate fat resources.

Although the difference in timing of immergence between successful and unsuccessful females was $>1$ week, the effect on emergence the following spring was $<2$ days. Dobson and Murie (1987) found that in years with late snowmelt and therefore late emergence and breeding, reproductive success was lower than in years when animals emerged early. There was a relatively small difference between successful and unsuccessful females in time of emergence compared with immergence, possibly because emerging and breeding as early as possible are advantageous for subsequent reproductive success of females. Offspring of later-mating females also might suffer higher mortality because of infanticide (Hoogland 1995). Early mating females also might be more likely to start hibernation earlier than later-mating females.

The high quality of forage from May to mid-July (Bennett 1997) might be the reason that mating date had little influence on weaning success of females. However, later-weaned juveniles had a much lower chance of survival to yearling age than early weaned young, probably because of diminishing quality of vegetation in late July and August. Juveniles have to increase their body weight considerably during the last few weeks of the active season to survive hibernation. Offspring weaned in mid-June (at around the peak of the plant growing season) might have a considerable advantage over juveniles weaned later when forage quality already has started to decline. Therefore, survival of young to yearling age rather than weaning success could be the evolutionary force for breeding as early as possible and to emerge from hibernation before the onset of the growing season of plants. However, early emergence in mountainous regions has its risks because it is not uncommon for late snowfalls to make it impossible for animals to feed for several consecutive days; snow also can disrupt mating and affect early pregnancy, leading to abortion (Morton and Sherman 1978; Neuhaus et al. in press).

The end of the molt was, on average, 2 weeks later in females that weaned a litter than in females that did not reproduce successfully. Similarly, nonreproductive female yellow-bellied marmot (Marmota flaviventris) initiated molting about 3 weeks earlier than reproductive females (Armitage and Salsbury 1993).

While some unsuccessful female Columbian ground squirrels started molting before the last juveniles of successful females emerged, I never observed successful fe- 
males molting before they weaned their young. Assuming that molt is energetically expensive, as shown in birds, ungulates, and European badgers (Klaassen 1995; Peréz-Barbería and Nores 1996; Siikamäki et al. 1994; Stewart and MacDonald 1997), the high energy expenditure associated with lactation may preclude molting until after weaning in successfully reproducing $\mathrm{Co}-$ lumbian ground squirrels.

The higher daily weight loss during hibernation in females that successfully weaned juveniles compared with unsuccessful ones could have several causes. Although the end of the molt was on average 2 weeks later in successful females, immergence was only on average 1 week apart. Hence, it could be that molt in successful females not only was delayed but also was a constraint. The insulative quality of the new pelage may not be optimal for late-molting animals, and that could lead to the higher daily weight loss. Late-immerging animals also might have less time to carefully choose and prepare their hibernacula compared with earlier-immerging females. If there are differences in quality of hibernacula, the better sites already might have been taken by earlier-immerging squirrels.

Despite the shorter hibernation of females that weaned young, successfully reproducing females lost more weight than unsuccessful females. Because unsuccessful reproducing females likely went into hibernation at greater weights than successful reproducing females, weight loss as a proportion of immergence weight also was significantly higher in successful females than in unsuccessful ones. In case of a delayed spring, this could be fatal for lighter females if they are forced to stay longer in their hibernacula.

A delay in immergence into hibernation and a delay in molt for successful reproducing females indicate patterns that likely are associated with energetic costs. Higher weight loss during hibernation for successfully reproducing females also indicates energetic costs of reproduction that may influence survival and future reproductive suc- cess. That females that bred early had a higher chance of producing juveniles surviving to yearling age suggests that the early start of the active season for the ground squirrels is driven by evolutionary pressure rather than energetic needs of adult female squirrels. The shorter active season followed by a longer hibernation of unsuccessfully reproducing females might increase their fitness by reducing predation pressure in summer. Successful females, in contrast, have to prolong their active season to meet the energetic costs of hibernation.

\section{ACKNOWLEDGMENTS}

For help in the field, I thank N. Blatter, N. Duvoisin, T. Grau, D. Haase, P. Herzig, A. Jaun, A. Lüscher, T. Lloyd, J. Murie, N. Pelletier, B. Reutter, C. Ruppen, S. Stevens, B. Studholm, S. Thiele, and P. Wittwer. The commission for travel grants of the Swiss Academy of Science supported the study. For constructive, critical comments on earlier drafts, I thank F. S. Dobson, J. O. Murie, and K. E. Ruckstuhl. The University of Calgary Kananaskis field station provided space and facilities.

\section{Literature Cited}

Armitage, K. B., And C. M. Salsbury. 1993. The effect of molt on oxygen consumption of yellowbellied marmots (Marmota flaviventris). Comparative Biochemistry and Physiology, A. Comparative Physiology 106:667-670.

ARNOLD, W. 1990. The evolution of marmot sociality: II. costs and benefits of joint hibernation. Behavioral Ecology and Sociobiology 27:239-246.

BARASH, D. P. 1989. Marmots: social behavior and ecology. Stanford University Press, Stanford, California.

Ben-DAvid, M. 1997. Timing of reproduction in wild mink: the influence of spawning Pacific salmon. Canadian Journal of Zoology 75:376-382.

Benkman, C. W. 1990. Intake rates and the timing of crossbill reproduction. The Auk 107:376-386.

BENNETT, R. B. 1997. Effects of variation on food quality on growth and survival of Columbian ground squirrels. M.S. thesis, University of Alberta, Edmonton, Alberta, Canada.

BoAg, D. A., AND J. O. MurIE. 1981. Weight in relation to sex, age, and season in Columbian ground squirrels (Sciuridae: Rodentia). Canadian Journal of Zoology 59:999-1004.

Churchill, S. K. 1994. Diet, prey selection and foraging behaviour of the orange horseshoe-bat, Rhinonyceris aurantius. Wildlife Research 21:115-130.

Dobson, F. S., M. J. Badry, and C. Geddes. 1992. Seasonal activity and body mass of Columbian 
ground squirrels. Canadian Journal of Zoology 70: $1364-1368$.

Dobson, F. S., And G. R. Michener. 1995. Maternal traits and reproduction in Richardson's ground squirrels. Ecology 76:851-862.

Dobson, F. S., AND J. O. Murie. 1987. Interpretation of intraspecific life history patterns: evidence from Columbian ground squirrels. The American Naturalist 129:382-397.

GauthiER, G. 1989. The effect of experience and timing on reproductive performance in buffleheads. The Auk 106:568-576.

Grindall, S. D., T. S. Collard, R. M. Beringham, AND T. M. R. BARCLAY. 1992. The influence of precipitation on reproduction by myotis bats in British Columbia. The American Midland Naturalist 128: 339-344.

Hoogland, J. L. 1995. The black-tailed prairie dog: social life of a burrowing mammal. The University of Chicago Press, Chicago, Illinois.

King, W. J., M. Festa-Bianchet, and S. E. Hatfield. 1991. Determinants of reproductive success in female Columbian ground squirrels. Oecologia 86: 528-534.

KLAASSEN, M. 1995. Moult and basal metabolic costs in males of two subspecies of stonechats: the European Saxicola torquata rubicula and the East African S. t. axillaris. Oecologia 104:424-432.

KomdeUR, J. 1996. Seasonal timing of reproduction in a tropical bird, the Seychelles warbler: a field experiment using translocation. Journal of Biological Rhythms 11:333-350.

MiCHENER, G. R. 1978. Effect of age and parity on weight gain and entry into hibernation in Richardson's ground squirrels. Canadian Journal of Zoology 56:2573-2577.

MicheneR, G. R. 1985. Chronology of reproductive events for female Richardson's ground squirrels. Journal of Mammalogy 66:280-288.

MiCHENER, G. R. 1989. Reproductive effort during gestation and lactation by Richardson's ground squirrels. Oecologia 78:77-86.

Mitchell, B., AND G. A. Lincoln. 1973. Conception dates in relation to age and condition in two populations of red deer in Scotland. Journal of Zoology (London) 171:141-152.

Morton, E. S., And K. C. Derrickson. 1990. The biological significance of age-specific return scheduled in breeding purple martins. Condor 92:10401050.

Morton, M. L., AND P. W. Sherman. 1978. Effects of a spring snowstorm on behavior, reproduction, and survival of Belding's ground squirrels. Canadian Journal of Zoology 56:2578-2590.

Murie, J. O., AND D. A. BoAg. 1984. The relationship of body weight to overwinter survival in Columbian ground squirrels. Journal of Mammalogy 65:688690.

Murie, J. O., AND M. A. Harris. 1982. Annual variation of offspring emergence and breeding in $\mathrm{Co}_{-}$ lumbian ground squirrels (Spermophilus columbianus). Journal of Mammalogy 63:431-439.
Neuhaus, P., R. B. Bennett, and A. Hubbs. In press. Effects of a late snowstorm and rain on survival and reproductive success in Columbian ground squirrels (Spermophilus columbianus). Canadian Journal of Zoology.

Newton, I., AND M. Marquiss. 1984. Seasonal trend in breeding performance of sparrowhawks. The Journal of Animal Ecology 53:809-829.

Norusis, M. J. 1994. SPSS Graduate Student Statistical Package (6.1). SPSS Inc., Chicago, Illinois.

Olsson, O. 1996. Seasonal effects of timing and reproduction in the King Penguin: a unique breeding cycle. Journal of Avian Biology 27:7-14.

OPPLIGER, A., H. Richner, AND P. Christe. 1994. Effect of an ectoparasite on lay date, nest-site choice, desertion, and hatching success in the great tit $(\mathrm{Pa}$ rus major). Behavioral Ecology 5:130-134.

Peréz-Barbería, F. J., AND C. Nores. 1996. Grazing activity of breeding and non-breeding female Canabrian chamois (Rupicapra pyrenaica parva). Ethology Ecology and Evolution 8:353-363.

RIEGER, J. F. 1996. Body size, litter size, timing of reproduction, and juvenile survival in the Unita ground squirrel, Spermophilus armatus. Oecologia 107:463-468.

Ritchie, M. E. 1990. Sociality of Columbian ground squirrels in relation to their seasonal energy intake. Oecologia 83:495-503.

Schöch, S. J. 1996. The effect of supplemental food on body condition and the timing of reproduction in a cooperative breeder, the Florida scrub-jay. Condor 98:234-244.

SiIKAmÄKi, P., M. Hovi, AND O. RÄtti. 1994. A tradeoff between current reproduction and moult in the pied flycatcher - an experiment. Functional Ecology 8:587-593.

SOKal, R. R., AND F. J. RoHLF. 1995. Biometry: the principles and practice of statistics in biological research. 3rd ed. W. H. Freeman and Company, New York.

SteVEns, S. D. 1998. High incidence of infanticide by lactating females in a population of Columbian ground squirrels (Spermophilus columbianus). Canadian Journal of Zoology 76:1183-1187.

Stewart, P. D., and D. W. MacDonald. 1997. Age, sex and condition as predictors of moult and the efficacy of a novel fur-clip technique for individual marking of European badger (Meles meles). Journal of Zoology (London) 241:543-550.

Verhulst, S., AND J. M. Tinbergen. 1991. Experimental evidence for a causal relationship between timing and success of reproduction in the great tit Parus m. major. The Journal of Animal Ecology 60: 269-282.

YounG, P. J. 1990. Hibernating patterns of free-ranging Columbian ground squirrels. Oecologia 83:504-511.

YounG, B. E. 1996. The effects of food, nest predation and weather on the timing of breeding in tropical house wrens. The Condor 96:341-353.

Submitted 21 April 1999. Accepted 7 September 1999.

Associate Editor was Robert K. Rose. 